\title{
INVESTIGATION OF THE CHANGE OF WOODED AREAS IN FOREST LAND IN RAUDONE ELDERSHIP
}

\author{
Puziene Ruta \\ Vytautas Magnus University, Lithuania
}

\begin{abstract}
Under the conditions of a global reduction in forest areas and climate change, it is important to preserve as many tree-covered areas as possible and understand change trends. The article purpose - aims at identifying forest area change trends of $19^{\text {th }}-20^{\text {th }} \mathrm{c}$. in the current forest land of the eldership Raudone. In the research, historical topographic maps compiled during different periods, and 2019 data from the forest registry are used. The research method of a comparative analysis is employed. The change in forest areas was analysed, and forest areas that remained unchanged for 200 years were identified. The comparison of current forest areas reflected in the cadastral data and forest areas of the considered period allowed identifying the tendency of assigning land the purpose of forest land. During the research, the period with largest forest areas was determined to be the $19^{\text {th }} \mathrm{c}$., and with the smallest $-1^{\text {st }}$ half of the $20^{\text {th }} \mathrm{c}$. During the Soviet period, forests areas were increasing, but did not achieve the same level as in the $19^{\text {th }} \mathrm{c}$.
\end{abstract}

Key words: maps of $19^{\text {th }}-20^{\text {th }}$ c., forest cadastre, forest areas, comparative analysis.

\section{Introduction}

In order to properly assess the current situation and plan future actions, knowledge and understanding of the past is required. Only by understanding past processes, their change trends, taking into account different factors influencing forest areas, we can understand and manage current processes, as well as plan the future in order to achieve the optimal result. Forests play an important role in improving the ecological situation and managing the climate change. Currently, during the time of global warming that may have catastrophic consequences, it is vital not to reduce forest areas and further expand them (Dagiliute, Kaktyte, 2013).

The forest change is a constant process that was taking place in the past and is still happening now. Before humans populated Europe, the forest change was caused by natural processes. When people started living here, an anthropogenic factor was added to the natural factors. Before the industrial revolution, the impact of humans on forests was of low significance due to small human population, primitive tools, low demand for timber and its products. In the conditions of scientific and industrial development and urbanization, this demand grew, and it negatively impacted forest areas (Birks, Tinner, 2016; Fedotova, Loskutova 2015; Hansen et al. 2013).

In order to understand the scale of the reduction of forest areas, it is important to identify former forest areas, simulate their change, taking into account the growth of the human population, as well as industrial, agricultural and urban development. For this purpose, it is expedient to identify the change in forest areas during different periods in order to analyse the impact of the anthropogenic influence that has been rapidly increasing during the past 300 years due to scientific achievements, industrial development and the population growth.

Former forest areas were researched a lot in the past by employing a palaeobotanical method on the basis of preserved historical documents and statistical data (He et al., 2008; Ralph et al., 2014; West, 1980). As the development of the cartography science progressed, an opportunity arose to monitor relatively recent changes by using topographic maps, including on the territory of the Republic of Lithuania. The current territory of the Republic of Lithuania was mapped for the first time when the Russian empire was compiling military topographic maps, then during the Lithuanian Interwar period and during Soviet times. The analysis of the area situation depicted in these maps allows observing changes of forest areas recorded in the cartographic works.

First, we must determine what will be considered forest in the scope of the present research. The definition of a "forest" differs from country to country, it may also differ within the same country, based on the changes in the legal base. "Forest" is understood differently in the spoken language and in legal definitions. Therefore, before starting the research, what is to be considered forest needs to be defined. Whether it is an area with trees growing on it, a legally regulated definition, or a forest definition chosen by the researcher. 
Legally, the notion of a forest is defined by the Law on Forestry of the Republic of Lithuania. Due to this law being amended, forest was understood differently as well. In 1996, a forest was defined in this law as follows: "Forest is a land area not less than 0.1 hectare in size covered with trees, other forest plants or vegetation-lost forest (cutting areas, burnt areas). Tree groups and narrow lines of trees up to 10 meters of width in fields, at roadsides, water bodies, in cities, in residential areas, and cemeteries, green hedges, single trees and bushes, parks planted and grown by man in urban and rural areas are not defined as forests" (Lietuvos Respublikos..., 1994).

Amendment that came into force in 2001 defines a forest as follows: "a land area not less than 0.1 hectare in size covered with trees, the height of which in a natural site in the maturity age is not less than 5 meters, other forest plants as well as thinned or vegetation-lost forest due to the acts of nature or human activities (cutting areas, burnt areas, clearings). Tree groups and narrow lines of trees up to 10 meters of width in fields, at roadsides, water bodies, in residential areas and cemeteries, green hedges, single trees and bushes, parks planted and grown by man in urban and rural areas are not defined as forests" (Lietuvos Respublikos..., 1994).

Amendment that came into force in 2015 defines a forest as follows: "a land area not less than 0.1 hectare in size covered with trees, the density of which is not less than 0.3 and the height in a natural habitat in the maturity age is not less than 5 meters, other forest vegetation, as well as a land area not less than 0.1 hectare in size, in which a stand is thinned or temporarily without tress due to human activities or natural factors (clearings to be planted with, cutting areas, dead stands). Greenery planted along road lanes, trees and shrubs growing in non-forest land plots managed on the basis of the right of trust by a manager of the public railway infrastructure, narrow - up to 10 metres - tree lines, green hedges, single trees and shrubs as well as the greenery planted on the non-forest land in urban and rural areas are not considered a forest" (Lietuvos Respublikos..., 1994).

As we can see, the initial legal regulation defines forest as a land area not less than 0.1 hectare in size covered with trees, later a condition is added that trees must be no less than 5 meters in height, and, finally, as a mandatory condition, their density is also added (Lietuvos Respublikos..., 1994).

Due to the changing definition of a forest, the accounting for forest areas may differ, therefore, for the research, a slightly different interpretation of the definition of a forest was chosen. From the $19^{\text {th }} \mathrm{c}$., when an area was mapped, an area covered with trees was marked by conventional signs denoting a forest, which, on the basis of its size, is appropriate to be depicted on a map. Therefore, the term "forest" will be used as a term denoting an area covered with trees (forest areas).

The legal base includes a term "forest land". It is not an analogous term for "forest". In the Law on Forestry of 2015, it is defined as "an area covered with forest - forest stands, as well as non-forest covered areas - cutting areas, dead stands, forest clearings, nursery areas, forest seed orchards, rawmaterial plantations, collections of clones, land assigned to afforestation. Forest roads, blocks, technological and fire break lines, areas covered by timber storage houses and other forest-related equipment (ditches, culverts, bridges, fire towers, etc.), recreation grounds, animal feed grounds, are ascribed to forest land as well. "As evident, forest land is not limited to only land covered with trees, it also includes land plots unrelated to growing trees, as, for example, timber storage houses" (Lietuvos Respublikos..., 1994).

The change of forest-covered areas is a pressing issue for the Republic of Lithuania, as well as Europe. In order to plan and regulate forest areas, it is important to know and understand their change trends. It is important to understand which forest areas remained unchanged throughout centuries, how many areas were cut/reforested.

The article purpose - aims at identifying forest area change trends of $19^{\text {th }}-20^{\text {th }} \mathrm{c}$. in the current forest land of the eldership Raudonè.

\section{Methodology of research and materials}

In accordance with the European practice, forest cover is calculated by forest land divided by the area of a selected territory. For the analysis of the declared forest cover of the $21^{\text {st }} \mathrm{c}$. eldership Raudone, a forest registry was chosen in order to compare the current declared forest cover of the area with the former forest cover of the territory calculated in accordance with the actual forest cover situation depicted in the cartographic materials. In this case, the notion of "forest cover" is ambiguous, but, for the purpose of this research, this exact variant was chosen intentionally. The aim is to compare the actual former forest cover with the current declared cover which is accepted as official. Moreover, the forest registry allows pinpointing areas of forest land. As a result, when having a forest registry and comparing 
it to areas previously covered in forests, tendencies of the basis for assigning a forest land purpose for an area on a certain territory can be identified.

For the analysis of the change in forest-covered areas, the eldership Raudone located in the district of Jurbarkas (Fig. 1) was selected; its area is $102.4 \mathrm{~km}^{2}$.

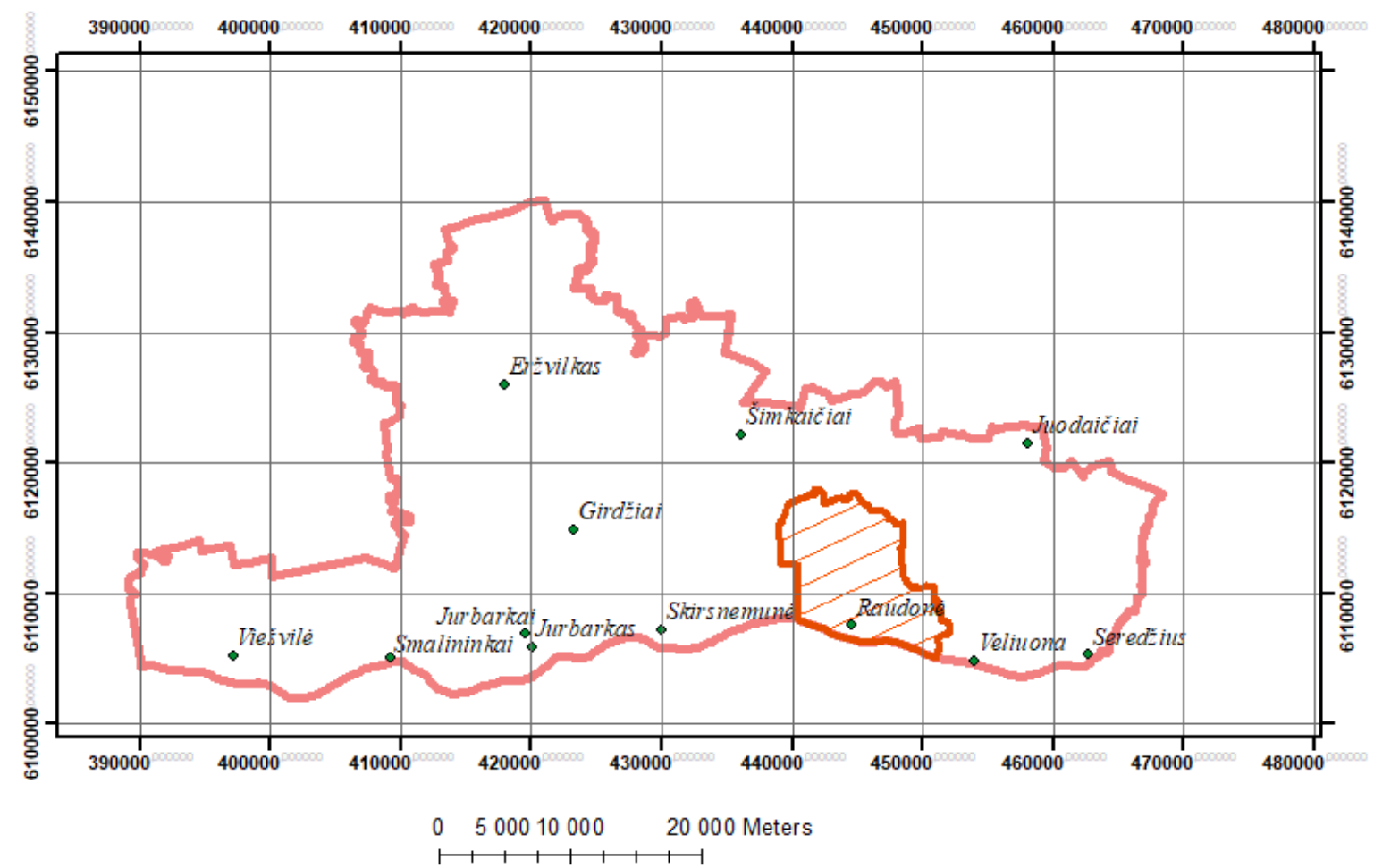

Fig. 1. Raudone eldership (district of Jurbarkas)

For analysing the change in forest areas, among other methods, topographic maps can be used. They allow monitoring the change of the Earth's cover, including the change of woodlands. Due to a generalization inherent to maps as well as cartographic methods, the outline of the depicted forest land is generalised, therefore, the macroscale change of the forest land may be analysed without expecting each line turn of a conventional sign to ideally match the outline of the forest land and reflect small configurations of land boundaries. Nevertheless, generalizing does not result in significant loss of forest areas, therefore, it can be stated that the absence of microscale changes does not have a significant impact on the result, and main forest change processes are sufficiently accurate and informative.

More accurate topographic maps of the Republic of Lithuania were started to be compiled in the $19^{\text {th }} \mathrm{c}$., when the triangulation network started to be developed, a need for military purposes arose for topographic maps with sufficient accuracy. As time went by, the territory of the Republic of Lithuania was mapped several times, therefore, the following maps were employed for the research:

- Topographic maps compiled by the Military Topography Department of the Tsarist Russia (Fig. 2, a)). Topographic maps of the European part of the empire compiled in the second half of the $19^{\text {th }} \mathrm{c}$. in the Tsarist Russia were published in 1860-1890. The scale is 1 English inch to 3 miles, what corresponds to M 1:126,000. The map page is rectangular, $58 \times 42 \mathrm{~cm}$, it corresponds to $73 \times 53 \mathrm{~km}$ at the location. The measurement accuracy of important objects is 50-200 m, of unimportant - 100$300 \mathrm{~m}$. In some instances, the tolerance reaches $500 \mathrm{~m}$ and more.

- 1:25,000M maps published by the Military Topography Department of Lithuania during the interwar period (Fig. 2, b)). The works of compiling topographic 1:25,000M maps during the interwar period in Lithuania were started in 1924. The published materials map the territory of the country of that time, the map page size is $47 \mathrm{x} 45 \mathrm{~cm}$. The publishing activities were performed by the Military Topography Department of the Military Headquarters, years of publication: 1930-1939.

- Soviet 1:50,000M topographic maps. Soviet 1:50,000M maps were compiled after the 1956-1957 renewal of the cartographic data and published in 1988 (Fig. 2, c)). For the renewal, aerial photos 
and location studies were used. The map was compiled in accordance with the coordinate system of 1942.
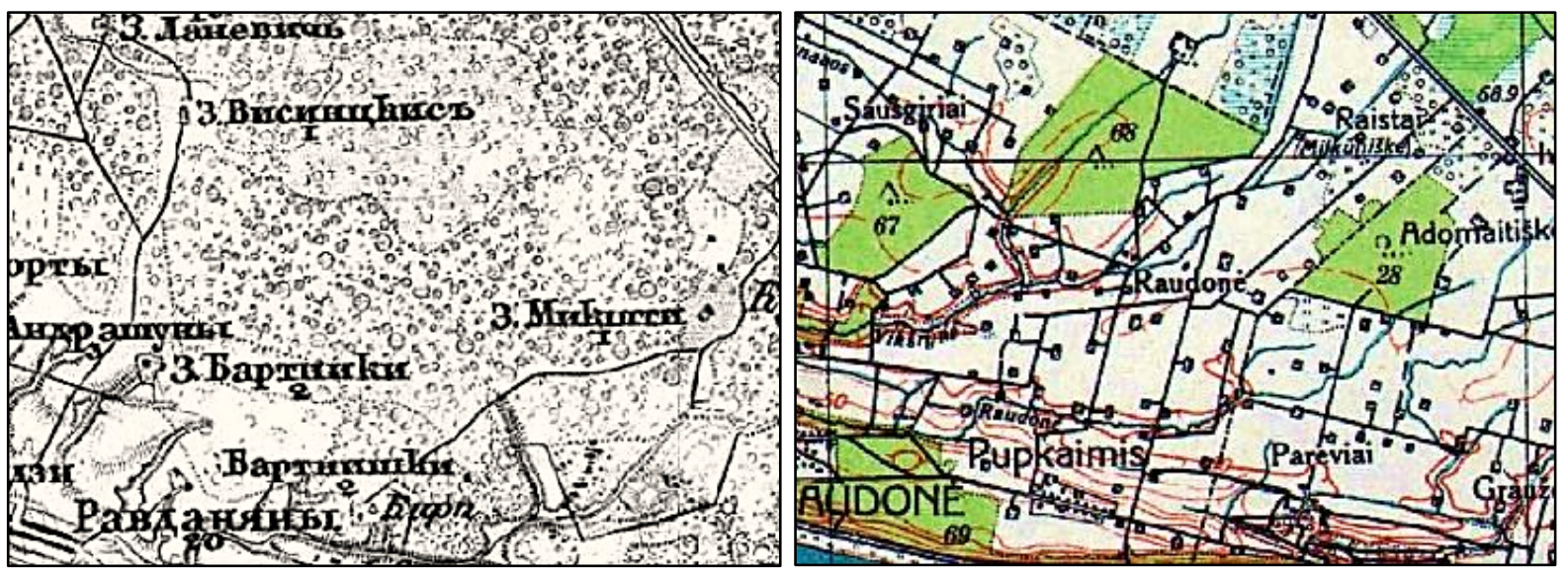

a)

b)

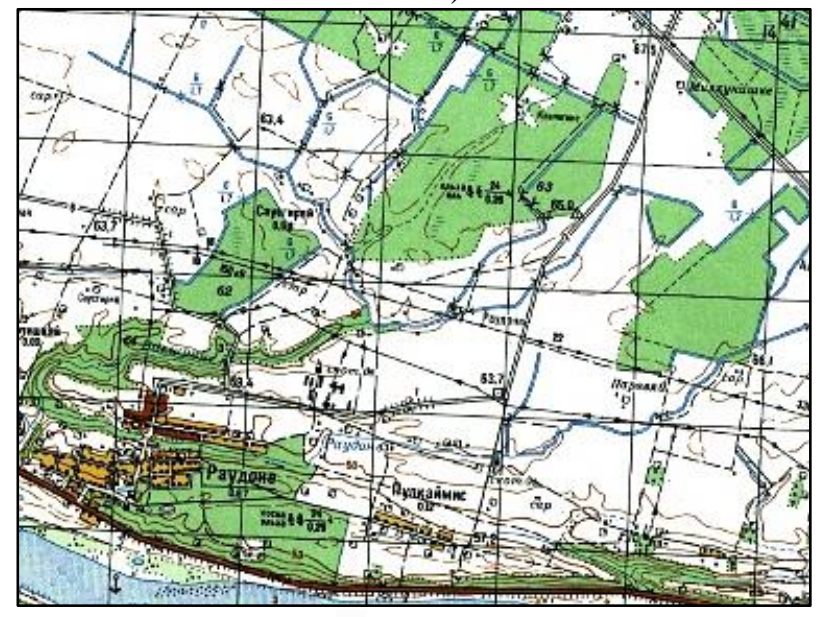

c)

Fig. 2. Fragment of maps: a) 1860-1890, b) $1930-1939$, c) 1988

The data from the forest registry was used in the research (State Forest Service, 2019) (Fig. 3); formed forest land plots can be seen, each land plot has its own cadastral number.

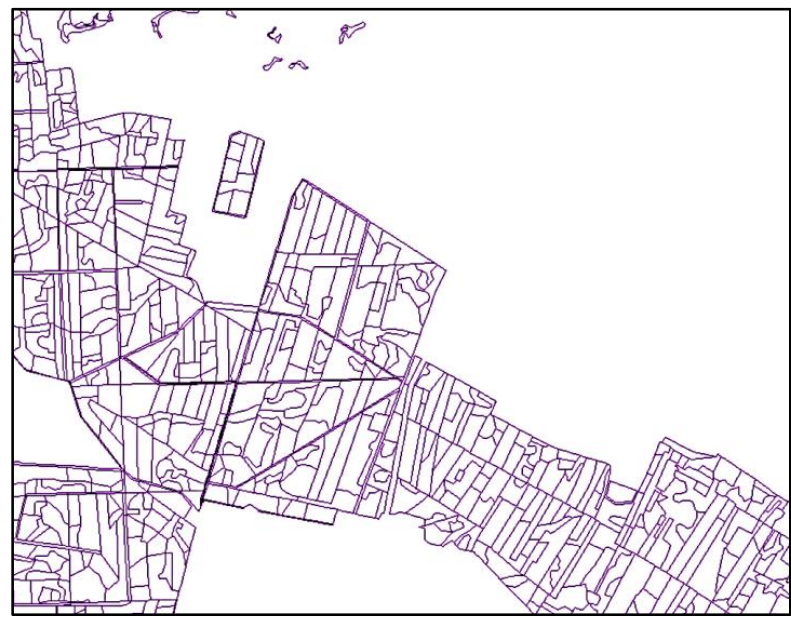

Fig. 3. Fragment of forest cadastre, 2019

The method of comparative analysis, ArcGIS software, maps of the 19th-20th c. and the data from the forest registry were used in the research. Due to the 19th c. maps being scanned, they had no orientation 
after being uploaded into the software. Objects remaining unchanged throughout time, e. g. churches, were selected for the orientation (construction years of churches as well as their affiliation with a faithbased community were thoroughly analysed in order to avoid instances when, after a church burned down, it was established in another building or mistaking churches of different faiths located relatively close to one another). A few of orientation corrections were carried out on the basis of bridges remaining from the 19th c. after studying their construction year and history. The remaining maps were downloaded from Geoportal website, they are provided to the user already with orientation.

The coordinate system LKS94 was chosen. Using the vectorisation method, forest layers of different periods were digitalised; their area was calculated. A layer of the forest registry was added on top, and the obtained results were compared.

\section{Discussions and results}

Forest-covered territories account for some land plots that, as time went by, were converted into agricultural land. Districts where conditions are not as favourable for agriculture are characterised by larger areas covered with forest and smaller agricultural land plots. The opposite is true as well: the more favourable conditions for agriculture are, the smaller areas are left for the forest. The district of Jurbarkas is located in central Lithuania, where the soil is characterised by the highest productivity score. The land productivity score in the district of Jurbarkas is 49.77 , and in the eldership Raudone -50.71 (https://www.geoportal.lt/map/). The relief is favourable for the agricultural development (https://www.arcgis.com/apps/webappviewer/index.html?id=d29c96b53bc740e38fb79f8532753544 ), its unevenness is observed only in river valleys and along Nemunas. Due to these reasons, the forest cover of the eldership is currently not large, however, it was different in the past, when the population was lower and farmers only had primitive tools for agricultural use.

After orienting and vectorising forest areas, a model vector forest layer is obtained in the $19^{\text {th }} \mathrm{c}$. map. The analysis of this data allowed determining forest areas. Borders of forest areas are not strict geometric lines, they curve, are of a natural configuration, are not restricted by plots of cultivated land, roads, river beds. There is less forest in the vicinity of the river Nemunas, along which, in the old times, trading used to be carried out using the waterway, it was also convenient to use the river for log driving. There are many homesteads in the forest, with small territories around them cut for agricultural purposes. However, the cartographic materials reveal documented cutting of forest areas as well. The map (Fig. 4) shows large areas of cut forest that constitute $8.5 \%$ of the total forest area of that time (Table 1):

Table 1

Change of forest areas in the 19th century

\begin{tabular}{|l|c|}
\hline & Forest areas, hectare \\
\hline Area of felled forests & 306.64 \\
\hline Forest area after felling & 3289.97 \\
\hline The total forest area before felling & 3596.61 \\
\hline
\end{tabular}

After the vectorisation of forest areas depicted in the maps of the Interwar period, we can see a completely different forest cover situation. The forest areas are significantly reduced, the borders of their land plots are strictly limited in geometrical shapes, there are no lines of natural growth, it is evident, that a significant amount of forest was cut in an organised manner, entire land plots were deforested. A forest usually ends with roads, streams. The majority of forests are surrounded by large cultivated land plots (Fig. 4).

The analysis of vectorised forest areas of the Soviet times reveals that forest areas are much larger in the Soviet maps when compared to the Interwar period. Forest areas are not as fragmented, a part of cultivated land was changed to forest. After the war, when some land was left uncultivated, in some places, the forest grew back on its own, in other places, a planned afforestation was carried out, therefore, the forest-covered areas increased.

The results of the forest area change analysis are provided in Table 2 and in Figure 4: 
Comparison of forest areas in the 19th-20th centuries

\begin{tabular}{|l|c|c|c|}
\hline Period & Forest areas: & $\begin{array}{c}\text { From eldership } \\
\text { area, \% }\end{array}$ & $\begin{array}{c}\text { Difference between areas, } \\
\text { hectare }\end{array}$ \\
\hline $19^{\text {th }} \mathrm{c.}$, to deforestation & 3596.61 & 35.1 & - \\
\hline $19^{\text {th }} \mathrm{c.}$, after deforestation & 3289.97 & 32.1 & -360.64 \\
\hline The $1^{\text {st }}$ half of the $20^{\text {th }} \mathrm{c}$. & 1626.09 & 15.9 & -1663.88 \\
\hline The $2^{\text {st }}$ half of the $20^{\text {th }} \mathrm{c}$. & 2394.11 & 23.4 & 768.02 \\
\hline
\end{tabular}

The analysis of the $19^{\text {th }} \mathrm{c}$. map reveals that 306.6 ha of forest was cut during that period. The comparison of the $19^{\text {th }} \mathrm{c}$. forest area with the forest area provided in Interwar maps reveals that in the $19^{\text {th }}$-the $1^{\text {st }}$ half of the $20^{\text {th }} \mathrm{c}$. the eldership lost as much as 1663.9 ha of forest, and, during the Soviet times, the forest area increased to $768 \mathrm{ha}$. The worst forest cover situation was during the Interwar period, when forest areas decreased by as much as $16.2 \%$.

During the Soviet times, the forest was partially restored, but it did not achieve the forest area of the $19^{\text {th }}$ c. During that time, the forest cover of the territory exceeded 30\%, that corresponds to the current European aspirational task and the territorial forest cover recommendations.

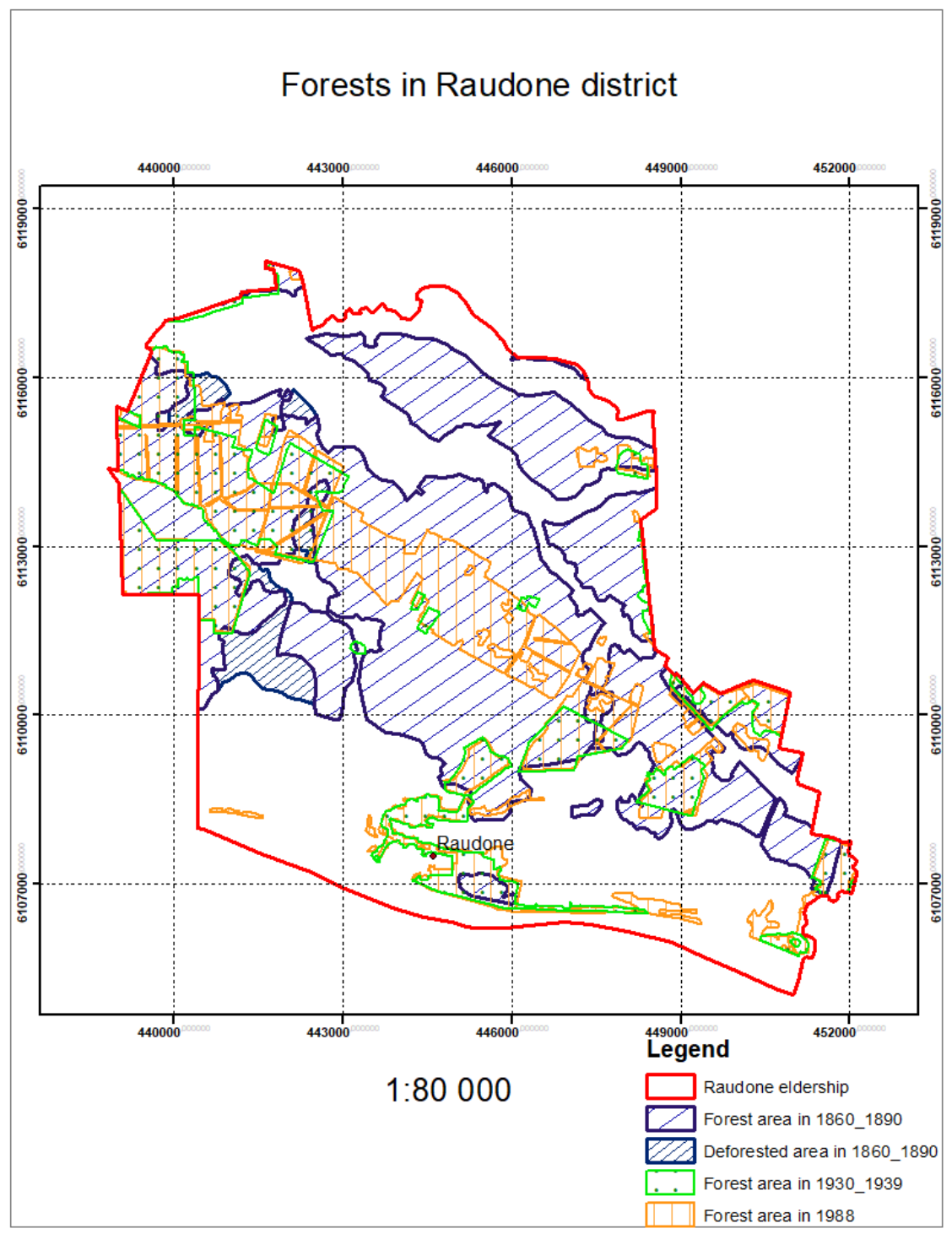

Fig. 4. Change of forest areas in the 19th - 20th c. 
Carrying on with the research, vectorised forest areas were overlapped, and there were areas identified that retained forest-covered areas for the entire 200 years. These areas cover an area of 1137.37 ha, i.e., $11.1 \%$ of the entire area of the eldership (Fig. 5), and mostly corresponds to the forest existing in the $1^{\text {st }}$ half of the $20^{\text {th }} \mathrm{c}$. Here, the forest remained during the entire $19^{\text {th }}-20^{\text {th }} \mathrm{c}$. period - during the entire analysed period, trees were growing and no agricultural activities were carried out. It is possible (it was not documented in the maps, so only an assumption can be made), that the forest was cut in some places, but later they were replanted or they regrew on their own, and there was no anthropogenic activity carried out that would destroy forest areas. These are the most stable forest areas, a kind of "centres" of forests, around which, as time went by, the forest developed/withered. These "centres" avoided the anthropogenic influence that conditioned the area change and remained unchanged during the analysed period - over two centuries. From the point of view of ecological sustainability, these territories are most stable.

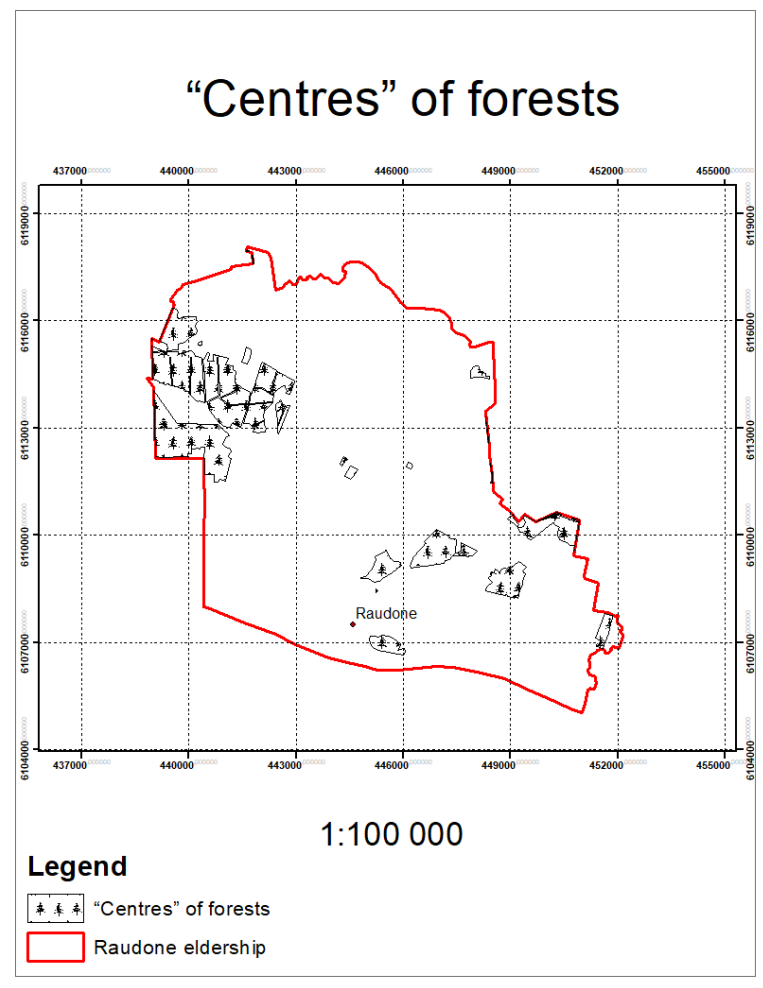

Fig. 5. "Centres" of forests $\left(19^{\text {th }}-20^{\text {th }}\right.$ c. $)$

The layer of cadastral data allows comparing the current declared forest cover situation (the forest cover, in accordance with forestry land area, is $25.7 \%$ ) with the former situation of forest-covered areas (Fig. 6). Moreover, the analysis of the tendencies of the layout of modern forests on the territory of the eldership can be carried out. We can see that the current forest land is the same actual place as former forest areas during the Soviet times. The cadastral data allows observing the tendencies of the land being assigned to "forest land" - in essence, with few exceptions, land plots that were covered in forests during the Soviet times are assigned this purpose. We can make an assumption that forest areas in the Raudone eldership have underwent no significant changes when compared to former forest areas of the $2^{\text {nd }}$ half of the $20^{\text {th }} \mathrm{c}$. The current forestry land area is as if a certain reflection of the centre of a former midwood - where the midwood once stood, there, through its centre, the current forest land lies today. 


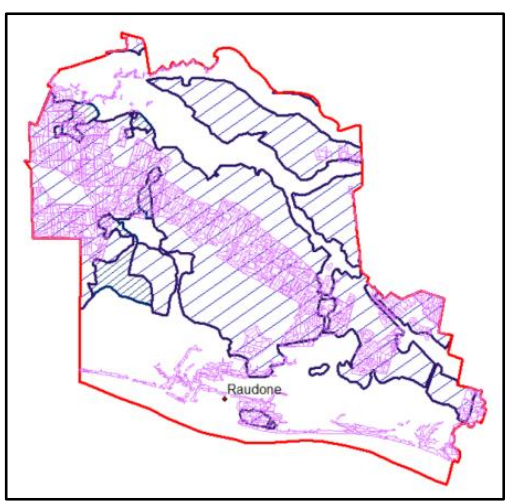

a)

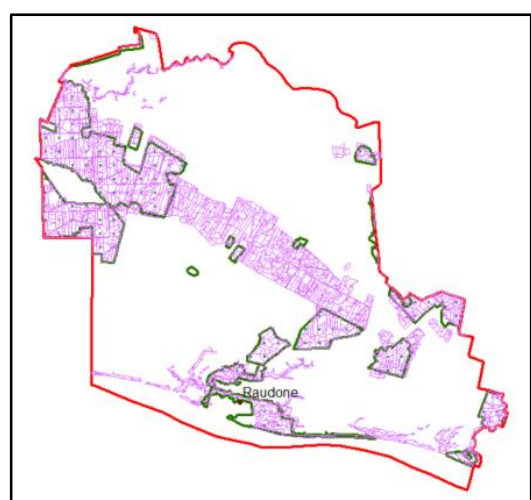

b)

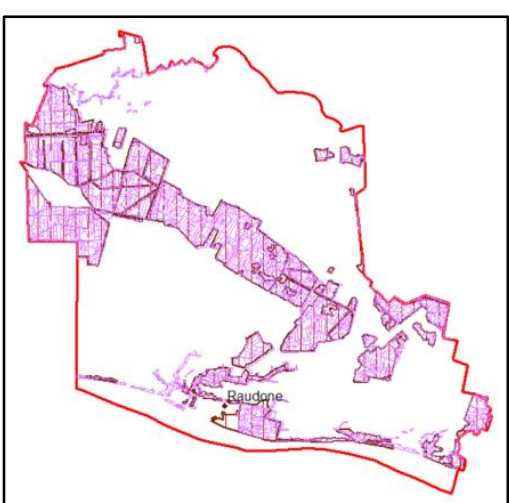

c)

Fig. 6. Overlap of $21^{\text {st }}$ c. forest register data layers and vectorized areas: a) 1860-1890, b) 1930 1939, c) 1988

\section{Conclusions and proposals}

- The forest cover of the Raudone eldership is smaller than the average of the Republic of Lithuania and constitutes $25.7 \%$. This percentage of forest cover is predetermined by favourable conditions for agricultural activity - a high soil productivity score and a relatively even relief.

- The forest cover level in the analysed territory in the 19th c. was not low, it was a little above $30 \%$, but, due to intensive cutting in the 1 st half of the 20th c., it fell to $15.9 \%$. In the 2 nd half of the 20th c., forest areas increase significantly and reach $23.4 \%$. These areas are smaller than in the 19th c., but $7.5 \%$ larger than in the 1 st half of the 20th c. that constitute 768 ha.

- During this entire period, forest borders changed significantly. In the 19th c., natural forest borders without strict contours may be observed. In the 1st half of the 20th c., forest borders are strictly defined, the impact of the anthropogenic activity is observed. In the 2nd half of the 20th c., forest borders partially naturalise, it is particularly evident along the shores of water bodies. A speculation can be made that the forest was allowed to regrow naturally at those locations.

- The purpose of forestry land assigned to land plots corresponds with the former forest areas of the Soviet times. A conclusion can be made that the current dislocation and volume of forestry land was influenced by the forest areas formed during the Soviet times, which, when comparing their cadastral data with the vectorised data, remained almost unchanged.

- The Raudonè eldership has only about $11.1 \%$ of forests that have not been converted into agricultural land or other land for two centuries and have remained unchanged and always have had trees growing in them. These are the most ecologically stable areas, but there are very few of them.

\section{References}

1. Birks H.J.B., Tinner W. (2016) Past Forests in Europe. In book: European Atlas of Forest Tree Species Publisher: Publication Office the Union. (https://boris.unibe.ch/80787/1/Past_forests_of_Europe.pdf ).

2. Dagiliute R., Kaktyte L. (2013) Miškingumo pokyčiai Lietuvoje ir itaka klimato kaitai 2010-2020 m. (Changes in forest cover in Lithuania and the impact on climate change in 2010-2020). Žmogaus ir gamtos sauga. pp. 48-51. (http://sauga.asu.lt/wp-content/uploads/sites/8/2016/01/48-51_Dagiliute 1.pdf ). (in Lithuanian).

3. Fedotova A., Loskutova M. (2015) Forests, Climate, and the Rise of Scientific Forestry in Russia: From Local Knowledge and Natural History to Modern Experiments (1840s-early 1890s). New Perspectives on the History of Life Sciences and Agriculture (pp.113-132). DOI: 10.1007/978-3-319-12185-7 7

4. Greg C. Liknes, Mark D. Nelson, and Daniel J. Kaisershot. (2013) Net Change in Forest Density, 1873-2001: Using Historical Maps to Monitor Long-term Forest Trends. (http://www.nrs.fs.fed.us )

5. Hansen M. C., Potapov P. V., Moore R., Hancher M. Turubanova S. A., Tyukavina A., Thau D., Stehman S. V., Goetz S. J., Loveland T. R., Kommareddy A., Egorov A., Chini L., Justice C. O., Townshend J. R. G. 
(2013). High-Resolution Global Maps of 21st-Century Forest Cover Change. Science, Volume 342, pp. 850853. DOI: $10.1126 /$ science. 1244693

6. He F., Ge Q., Dai J., Rao Y. (2008) Forest change of China in recent 300 years. J. Geogr. Sci., 18, pp. 5972. https://doi.org/10.1007/s11442-008-0059-8

7. Geoportal.lt. https://www.geoportal.lt/map/ [2021-01-02 ].

8. Lietuvos reljefas.

https://www.arcgis.com/apps/webappviewer/index.html?id=d29c96b53bc740e38fb79f8532753544 [202101-02].

9. Lietuvos Respublikos Miškų ịstatymas (The Republic of Lithuania Law on Forests), (1994) No. I-671 Vilnius. (https://e-seimas.lrs.lt/portal/legalAct/lt/TAD/TAIS.6036/kvlNKCdVIL ). (in Lithuanian).

10. Ralph M. F., Woodbridge J., Neil R. (2015) From forest to farmland: pollen-inferred land cover change across Europe using the pseudobiomization approach. Global change biology, Volume 21, Issue3, p.p. $1197-$ 1212. https://doi.org/10.1111/gcb.12776

11. West R. G. (1980) Pleistocene forest history in east Anglia. New Phytologist, Volume 85, Issue 4, pp. 571 624. https://doi.org/10.1111/j.1469-8137.1980.tb00772

12. William B. Meyer and B. L. Turner. (1992) Human Population Growth and Global Land-Use/Cover Change. Annual Review of Ecology and Systematics, Volume 23, pp. 39-61. https://doi.org/10.1146/annurev.es.23.110192.000351

\section{Information about author:}

Ruta, Puziene, doctor, associated professor, Institute of Land management and Geomatics, Vytautas Magnus University Agriculture Academy. Studentų str. 11, LT-53361 Akademija, Kaunas distr., +37037 752 272, ruta.puziene@vdu.lt. Fields of interest: geographic information systems, surface modelling, history of geodesy and cartography. 